\title{
Characteristics of dissolved organic matter in shallow groundwater in the Hetao basin
}

\author{
Wen Qiao ${ }^{1,2}$, Huaming Guo ${ }^{1,2, *}$, Quan $\mathrm{Shi}^{3}$, and Bo Zhao ${ }^{1,2}$ \\ ${ }^{1}$ State Key Laboratory of Biogeology and Environmental Geology, China University of Geosciences, \\ Beijing 100083, PR China \\ ${ }^{2}$ School of Water Resources and Environment, China University of Geosciences (Beijing), Beijing \\ 100083, PR China \\ ${ }^{3}$ State Key Laboratory of Heavy Oil Processing, China University of Petroleum, Beijing 102249, PR \\ China
}

\begin{abstract}
Dissolved organic matter (DOM) in both high As groundwater and low As groundwater were sampled from the Hetao basin and characterized by FT-ICR-MS for OM molecular characteristics. Results show that the greater number of molecular formulas was identified in DOM of high As groundwater (5125), compared to the number in DOM of low As groundwater (3603). Among them, lignins and aromatic structures were the most abundant compounds in both high As groundwater and low As groundwater, with 4434 formulas and 2944 formulas identified, respectively. The number of biodegradable compounds (aliphatic/proteins, lipids, and carbohydrates) was less in high As groundwater (197) than that in low As groundwater (279). Higher proportion of lignins and aromatic structures $(86.5 \%)$ would lead to complexation between As and DOM, which enhanced As mobility. On the other hand, higher proportion of lignins and aromatic structures and lower proportion of bioavailable compounds in high As groundwater supported the hypothesis that more bioavailable compounds were consumed and resulted in the enrichment of lignins and aromatic structures and As release into groundwater.
\end{abstract}

\section{Introduction}

There is a consensus that high As groundwater is the result of sediment As released into groundwater under reducing conditions, stimulated by microbially mediated organic matter, leading to the reduction of As-bearing Fe(III) oxides [1]. However, details of these chain reactions still kept unknown, limiting the ability to explore the mechanisms of the patchy nature of As distribution [2,3]. For example, the source of organic matter fuelling microbial reactions still kept disputed, which might come from recharged surface water [1, $4,5]$, or be released from historical deposits $[6,7]$. On the other hand, the reactivity of organic matter is the key factor governing redox processes in aquifers, especially the processes involving As release. Quantitative studying the reactivity of organic matter is a good approach to probe what kind of organic matter is responsible for As mobilization.

* Corresponding author: hmguo@cugb.edu.cn 
Recently, anoxic incubation experiments of sediments in aquifer recharge waters indicated that all types of organic compounds could be microbially transformed, although some complex compounds with aromatic rings were thought molecularly recalcitrant [8]. Thus, which part of organic matter is responsible for As mobilization needs to be investigated.

Fourier transform ion cyclotron resonance mass spectrometry (FT-ICR-MS) is capable of characterizing thousands of molecular formulas in natural organic matter, supporting quantitative classifications and comparisons. In this study, we have used FT-ICR-MS to characterize molecular formulas of dissolved organic matter (DOM) from high As groundwater and low As groundwater, which might help us probe the dissolved organic matter responsible for As mobilization.

\section{Materials and methods}

\subsection{Samples and preparation}

Two groundwater samples were collected in the Hetao basin. Sample 2 had As concentration of $1.0 \mu \mathrm{g} / \mathrm{L}$ and DOC concentration of $2.22 \mathrm{mg} / \mathrm{L}$, while sample 4 had As concentration of $784 \mu \mathrm{g} / \mathrm{L}$ and DOC concentration of $11.9 \mathrm{mg} / \mathrm{L}$. Samples for FT-ICR-MS analysis were filtered through $0.45 \mu \mathrm{m}$ polycarbonate filters and stored in $100 \mathrm{~mL}$ brown glass bottles.

\subsection{FT-ICR-MS analysis}

Before the FT-ICR-MS analysis, solid phase extraction was conducted to concentrate dissolved organic matter. During the processes, each sample was pumped through a PPL solid-phase extraction cartridge $(0.5 \mathrm{~g}, 6 \mathrm{~mL}$, Agilent, USA) at $5 \mathrm{~mL} / \mathrm{min}$. The cartridges were previously rinsed with methanol (LC-MS grade, Thermo Fisher) and acidified by $\mathrm{HCl}$ (p.a. grade, Merck, Germany, diluted to $\mathrm{pH} 2$ by HPLC Milli-Q water) before elution. Immediately after extraction, DOM was eluted by $10 \mathrm{~mL}$ methanol (LC-MS grade, Thermo Fisher). All extracted DOM samples were analysed using a Bruker Apex ultra FT-ICR MS equipped with a 9.4-T Apex-ultra FT-ICR-MS equipment at the State Key Laboratory of Heavy Oil Processing, China University of Petroleum [9].

\subsection{Data processing}

Molecular formulas were grouped according to their elemental compositions into $\mathrm{CHO}$, CHON, CHOS, CHONS compounds. Based on van Krevelen diagrams, organic matter is divided into seven classes of compounds, including lipids, aliphatic/proteins, lignins, carbohydrates, unsaturated hydrocarbons, aromatic structures and others [9]. Boundaries of the classification are listed as following:

Lipids, $\mathrm{H} / \mathrm{C}=1.5-2.0, \mathrm{O} / \mathrm{C}=0-0.3$; Aliphatic/proteins, $\mathrm{H} / \mathrm{C}=1.5-2.2, \mathrm{O} / \mathrm{C}=0.3-0.67$; Lignins, $\mathrm{H} / \mathrm{C}=0.7-1.5, \mathrm{O} / \mathrm{C}=0.1-0.67$; Carbohydrates, $\mathrm{H} / \mathrm{C}=1.5-2.4, \mathrm{O} / \mathrm{C}=0.67-1.2$; Unsaturated hydrocarbons, $\mathrm{H} / \mathrm{C}=0.7-1.5, \mathrm{O} / \mathrm{C}=0-0.1$; Aromatic structures, $\mathrm{H} / \mathrm{C}=0.2-0.7$, $\mathrm{O} / \mathrm{C}=0-0.67$; Others, $\mathrm{H} / \mathrm{C}=0.6-1.5, \mathrm{O} / \mathrm{C}=0.67-1.0$.

\section{Results and discussion}

In total, 5125 mono-isotopic molecular formulas were identified in sample 4, much higher than that of 3603 in sample 2 (Fig. 1). H-to-C ratios of DOM moleculars ranged from 0.4 to 1.75 in sample 4 , being lower than that in sample 2 with a range of $0.6-1.83$. On the 
contrary, O-to-C ratios of DOM moleculars showed higher values in sample 4 (0.2-0.93), compared to those in sample 2 (0.15-0.88).

Of the total identified molecular formulas, CHON formulas were the most abundant molecular in both high As groundwater (sample 4) and low As groundwater (sample 2), proportionly accounting for around $48.1 \%$ and $43.1 \%$, respectively. Considering the number of $\mathrm{N}$ element in $\mathrm{CHON}$ formulas, they were further subdivided into three different formulas, including $\mathrm{CHON} 1, \mathrm{CHON} 2$, and $\mathrm{CHON} 3$, among which $\mathrm{CHON} 1$ formulas were proportionately the largest $\mathrm{CHON}$ formulas both in high As groundwater (56\%) and low As groundwater (62\%). Low As groundwater (sample 2) contained almost the same proportions of CHON2 and CHON3 formulas (around 19\%), while CHON2 formulas (31\%) were around 3 times as high as CHON3 formulas (13\%) in high As groundwater (sample 4).
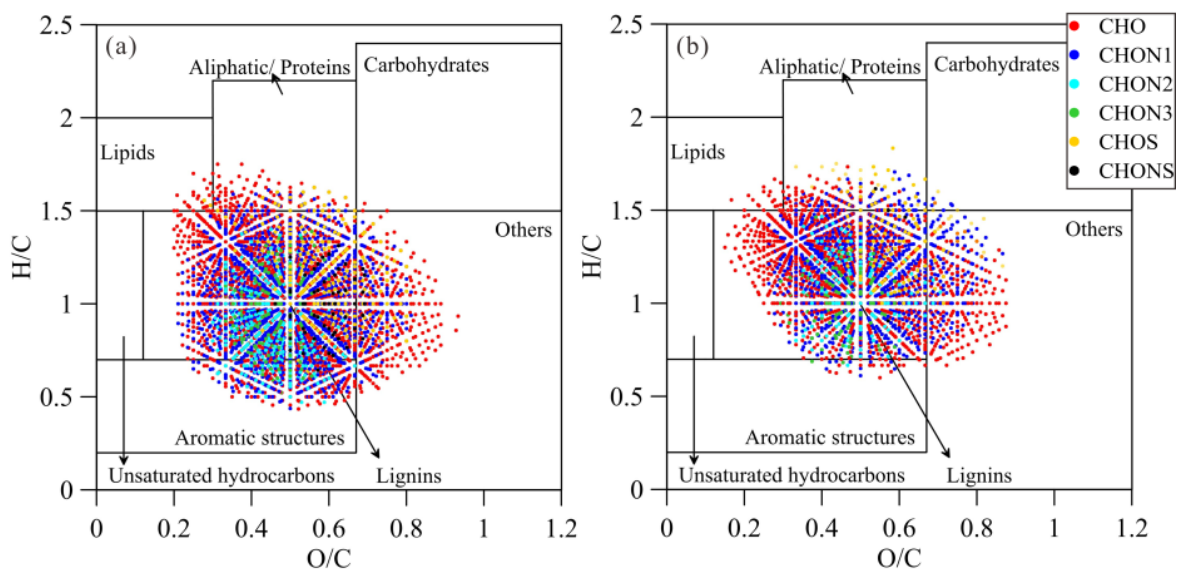

Fig. 1. Formulas classification of DOM formulas in (a) high As groundwater (sample 4), and (b) low As groundwater (sample 2).

A large proportion of $\mathrm{CHO}$ formulas was found in both high As groundwater $(41.3 \%)$ and low As groundwater $(41.0 \%)$, spreading a wide distribution throughout the van Krevelen diagram (Fig. 1). The proportion of CHOS and CHONS compounds were small, with around 10.5\% in high As groundwater and around 15.8\% in low As groundwater.

Among the seven classified group compounds (Fig. 1), lignins were the most abundant compounds, with 3872 formulas and 2912 formulas indentified in high As groundwater (sample 4) and low As groundwater (sample 2), respectively. Another rich compounds in high As groundwater were aromatic structures (562 formulas), much higher than the number identified in low As groundwater (32 formulas). The much greater number of lignins and aromatic structrues in high As groundwater (4434 vs. 2944 in low As groundwater) might be responsible for high groundwater As, since both of the compounds showed strong complexabilities with As [10, 11], which increased As mobility. Aliphatic/proteins were relatively abundant in low As groundwater (number 249, proportion 6.9\%) than those in high As groundwater (165, 3.2\%). Lipids and carbohydrates were coincidently rare in both high As groundwater and low As groundwater, with only 32 and 30 formulas identified, respectively. Aliphatic/proteins, lipids and carbohydrates were believed as biodegradable compounds [8]. These compounds occupied only $3.8 \%$ of the total formulas in high As groundwater (197 formulas), while it was 7.7\% in low As groundwater (279 formulas). The greater number of lignins and aromatic compounds and the lower number of bioavailable compounds in high As groundwater may support the hypothesis that microbe metablism of biodegradable compounds resulted in the low number of these compounds and the enrichment of lignins and aromatic structures. The 
consumption of biodegradable compounds caused the reduction of $\mathrm{Fe}$ (III) oxides and release of As. The hypothesis should be further studied from more comparable groundwater samples and molecular characteristics of sediment organic matter.

\section{Conclusion}

Two groundwater samples, one sampled in high As aquifer and the other in low As aquifer in the Hetao basin, were studied by FT-ICR-MS. Results showed that high As groundwater might be related to the consumption of biodegradable compounds (aliphatic/proteins, lipids and carbohydrates) in groundwater, leading to depletion of these bioavailable compounds and enrichment of lignins and aromatic structures. In addition, the greater number of lignins and aromatic structures would enhance As mobilization via complexation. Further studies are reqiured to investigate molecular characteristics of sedimentary organic matter.

The study was financially supported by the National Natural Science Foundation of China (grant No. 41825017 and 41672225), the program of China Geology Survey (No. 12120113103700), the Fundamental Research Funds for the Central Universities (grant No. 2652013028), and the Fok Ying-Tung Education Foundation, China (grant No. 131017).

\section{References}

1. M.L. Polizzotto, B.D. Kocar, S.G. Benner, M. Sampson, S. Fendorf, Nature 454, 505-509 (2008)

2. B.J. Mailloux, E. Trembath-Reichert, J. Cheung, M. Watson, M. Stute, G.A. Freyer, A.S. Ferguson, K.M. Ahmed, M.J. Alam, B.A. Buchholz, J. Thomas, A.C. Layton, Y. Zheng, B.C. Bostick, A. van Geen, P. Natl. Acad. Sci. 110, 5331-5335 (2013)

3. L. Charlet, D.A. Polya, Elements 2, 91-96 (2006)

4. C.F. Harvey, C.H. Swartz, A.B.M. Badruzzaman, N. Keon-Blute, W. Yu, A. Ali, J. Jay, R. Beckie, V. Niedan, D. Brabander, P.M. Oates, K.N. Ashfaque, S. Islam, H.F. Hemond, M.F. Ahmed, Science 298, 1602-1606 (2002)

5. R.B. Neumann, K.N. Ashfaque, A.B.M. Badruzzaman, M.A. Ali, J.K. Shoemaker, C.F. Harvey, Nat. Geosci. 3, 46-52 (2010)

6. M.V. Schaefer, S.C. Ying, S.G. Benner, Y.H. Duan, Y.X. Wang, S. Fendorf, Environ. Sci. Technol. 50, 3521-3529 (2016)

7. D. Postma, F. Larsen, T.T. Nguyen, T.K.T. Pham, R. Jakobsen, Q.N. Pham, V.L. Tran, H.V. Pham, A.S. Murray, Nat. Geosci. 5, 656-661 (2012)

8. L.E. Pracht, M.M. Tfaily, R.J. Ardissono, R.B. Neumann, Biogeosciences 15, 1733-1747 (2018)

9. Z.W. Yuan, C. He, Q. Shi, C.M. Xu, Z.S. Li, C.Z. Wang, H.Z. Zhao, J.R. Ni, Environ. Sci. Technol. 51, 8110-8118 (2017)

10. Y.F. Xu, W. Xiong, X.K. OuYang, Q.D. Yu, L.Y. Yang, W.N. Li, Adv. Mater. Res. 554-556, 2080-2084 (2012)

11. V.C. Pandey, N. Singh, J. Geochem. Explor. 157, 77-80 (2015) 